\title{
REFoRM OF IRRIgATION MANAGEMENT AND INVESTMENT Policy in African Development ${ }^{1}$
}

\author{
K William Easter and Slim Zekri \\ Applied Economics, University of Minnesota, St. Paul
}

\begin{abstract}
This paper examines the reform of water and irrigation management in Africa and compares it with similar reforms in Asia. Several things are evident from the review. First, Sub-Saharan Africa (SSA) is at an earlier stage of irrigation development and reform than Asia. Second, the articulated need for reform is much stronger in Asia than it is in SSA. Third, the productivity of small-scale irrigated farms is significantly lower in SSA compared to Asia. Thus any irrigation investment strategy in SSA should be different from Asia and focus on increasing small-farm productivity as well as small-scale irrigation projects. Finally, all direct government irrigation investments should be done jointly with decisions regarding the type of project management.
\end{abstract}

JEL O13, 32, Q16

\section{1}

\section{Introduction}

This paper reviews the water and irrigation management experienced in Africa to see if these same key factors that are limiting irrigation productivity in Asia are also limiting it in Africa. Irrigation has not been as important a part of Africa's past development strategies as it has been in Asia but water scarcity is growing in Africa. Still, Africa has not been plagued as much by large, top-down managed irrigation systems as has Asia. The review considers five key water management reforms and asks whether any of these reforms are needed in Africa. Reforms in a number of countries are used to illustrate different approaches and constraints that have raised the transaction cost of reform.

\section{2}

\section{Reform strategy and transaction costs}

There is now consensus concerning the strategy to reform water and irrigation management in Asia as reflected in the World Bank's water policy paper (World Bank, 1993). However, it is not clear that this same strategy will work as well in Africa. For example, irrigation development is at an earlier stage in Africa and modernisation of existing systems may be less important. Still, in countries like South Africa, Morocco and Tunisia, irrigation modernisation is needed. Furthermore, Burt and Styles (1998) found, in their review of irrigation projects for the World Bank, that most of the systems that are not correctly designed are difficult to operate.

\subsection{Irrigation reform}

The reform strategy delineated by Easter (2000: 372 ) and the World Bank's water policy paper (World Bank, 1993: 65-79) as a means for modernising water and irrigation management includes five basic actions:

1 Reform the legal, institutional and organisational framework for managing water resources so that the management 
units internalise the costs of water provision and are accountable for providing quality service.

2 Develop better economic incentive systems including improved water pricing and water markets.

3 Fully account for the environmental impacts of water use when designing, constructing, and managing irrigation systems, including the external impacts that are created within an irrigation system by return flows and fluctuations in water releases from reservoirs. This involves taking a basin-wide approach to water management, including both surface water and groundwater basins, and improving watershed management capabilities.

4 Reform delivery of agricultural technical assistance in irrigation areas so that it complements irrigation improvements. This will require mutual respect and close cooperation between the irrigation and agriculture ministries.

5 Improve water investment decisions by considering the full range of benefits and costs that are created by water development. New project investments and investments to improve exiting irrigation systems must have significant user input and use appropriate infrastructure and technology (Easter, 2000: 372).

What we are concerned about in this paper is whether or not this strategy is appropriate for Africa and if it is, whether it can be implemented given that some of the stakeholders will not gain and may even be worse off. The losers are likely to be overstaffed irrigation and water supply agencies, farmers at the head of irrigation canals, and higher income urban homeowners and business owners. The latter two may have to pay higher water fees for water purchased from farmers.

\subsection{Lowering reform costs}

In general it has been difficult to initiate effective water reforms. This has been the case even when public entities have followed Briscoe's (1997: 153) suggestions and reforms were started only after there was "a powerful articulated need for reform". The articulated need might be part of a country's effort to privatise public sector activities as happened in Chile, or as a response to severe water management problems as occurred in Andhra Pradesh, India. Andhra Pradesh and Chile also followed Briscoe's charge to involve stakeholders in reform discussions and to address their fears, concerning possible changes, in an effective and understandable manner. His third recommendation, that one should start with the relatively easy problems first and be sensitive and innovative in adapting general principles to different institutional and environmental situations, was followed in Chile but not in Andhra Pradesh. Finally, as Briscoe says, there is no silver bullet or panacea; the reform must fit a county's institutions and resources.

The process of reform is likely to be slow. Water agencies have a difficult time changing their supply-based approach to solving water problems. This is understandable given the large investments in supply development that have been made in the past by international agencies and developing countries. In contrast, policies involving demand-side solutions have been difficult to enforce and are unpopular with stakeholders in most developing countries.

\subsection{Transaction costs}

To introduce water reform effectively the transaction costs of reform have to be reduced. To reduce the transaction costs of changing government policy, one of the key steps is to reduce the expenses of organising and involve the stakeholders in specific water management reforms. Transaction costs include search and information costs, bargaining and decision costs, and monitoring and enforcement costs (Dahlman, 1979: 141-62). Some specific tasks that will be added to the transition costs of water reform include designing regulations for allocating water in an open and transparent manner, developing water delivery schedules in conjunction with stakeholders, enacting water-use rights and procedures to register them, designing transparent review procedures for water-use rights applications, and conducting open hearings concerning disputes 
over water allocation and water-use rights.

Transaction costs are likely to increase as the diversity and number of parties involved increase. Consequently, reforming large irrigation systems with a large number of smallscale farms is likely to be difficult and involve high transaction costs. Williamson (1985: 1718 ) argues that a key reason for changes in economic organisation is to reduce transaction costs. The same argument can be made for reforming the institutional and organisational arrangements for irrigation systems and water agencies. Thus, a key question is what institutional or organisational reforms will reduce transaction costs of improving water management. To help answer this and other questions, one can evaluate the experience of countries that have reformed their water sector. For example, several countries that reformed their economies found that they could make dramatic changes in their water institutions (Chile, Australia, Mexico, and South Africa, for example). Combining economic reforms with reforms in water management reduced the transaction costs of changing institutional arrangements for water management.

\section{3}

\section{Reform of irrigation management}

In contrast to Asia, the need for reform in the water sector does not appear to have been given sufficiently high priority in most of Africa. Thus, it appears that Africa does not meet Briscoe's first requirement. Several exceptions to this may be South Africa and several North African countries. Consequently, we will focus the analysis more on these countries to see what progress they have made in reform. In those African countries that have tried to reform water management, have they introduced any of the five reforms listed above?

\subsection{Legal, institutional and organisational reform}

A number of the leading irrigating countries have turned over some parts of irrigation management to Water User Associations (WUAs) and have done so with varying degrees of success. A key institutional reform was to give WUAs authority over water management and cost recovery. To illustrate the range of success, four middle-income developing countries - Mexico, Tunisia, Morocco and South Africa - will be reviewed in this section which draws on the paper by Zekri and Easter (2003).

Mexico began establishing WUAs in 1990 and is considered a fairly successful reform experience with 400 WUAs (average size 7600 ha) operational by 1997. A survey of 6 per cent of the districts showed that water use efficiency and maintenance had improved with water charges going up in a majority of districts, and increasing by over 500 per cent in some cases. Government subsidy dropped to only 15 per cent of the operation and maintenance (O\&M) costs in the transferred districts. Many WUAs used bank loans to make significant investments in repair or modernisation of their infrastructure. Since more than 90 per cent of farmers paid their irrigation assessment charges, partly because farmers have to pay the irrigation charges in advance of receiving WUA service, the irrigation assessments acted as loan guarantees.

The skills of hired technical staff have increased the effectiveness of Mexico's WUAs. In many districts, WUAs have assisted their members in obtaining inputs and renting machinery. By the end of 1996, eight limitedresponsibility companies, which are federations of WUAs, were providing services to the WUAs. These eight companies are interested in expanding their services beyond just operations, maintenance and management of the major infrastructure (Palacios, 1999: 20). The current reforms have focused on the larger schemes and farms, while the more difficult task, which has just started, is the transfer of water management on smaller schemes and farms (Simas, 2002: 152). One of the major reasons for the positive Mexican experience, was the commitment to reform by the President.

Management in Morocco turnover did not begin until 1994. In their review of the large irrigation of Gharb, which covers 250000 ha, El Hasnaoui, Boulassel and Raki (2002) report that WUAs were ineffective because of 
administrative and institutional failures. First, the clearly stipulated responsibilities of the public agencies and WUA were not followed. For example, the water agency did not return 20 per cent of the water charges to the WUA (as promised) owing to restrictions imposed by the Finance Ministry. Second, the conveyance system was in poor condition and unreliable. Third, farmers lacked access to markets and credit. In contrast, the traditional irrigation systems in the south have had a more positive experience with WUAs since the farmers have traditionally had greater water management responsibilities.

South Africa has experienced both success and failure in its establishment of WUAs because of the differences in institutional arrangement. The Irrigation Boards (IB), the White Settlement Schemes (WSS) and the Small Irrigation Schemes (SIS) each have a different institutional arrangement. Perret (2002: 295) found that most IBs changed quickly into WUAs soon after enactment of the new [National] Water Act. The 300 IBs were already primarily private, farmer-managed, water systems with a management board or committee. Since the government-developed WSS schemes involved farmer-owned private land, management turnover and formation of WUAs went fairly quickly. In contrast, the SIS management turnover was done in a different institutional setting and was not successful. Only ten pilot WUAs were formally established among 300 schemes countrywide. Part of the problem was that the SISs have an average farm size of less than 2 ha and farmers have only a permission certificate to occupy the land, which provides exclusive individual, life-time usufructuary land rights. Shah, Koppen, Merry, Lange and Samad (2002: 6-11) list a number of reasons why the SISs failed including the small farm size, high management costs of WUAs due to the large number of users, poor access to markets, low productivity of farms, and a high level of O\&M costs relative to gross margins. The success of the IBs was due primarily to the fact that management turnover merely formalised and legitimised high de facto farmer participation in already well-managed irrigation schemes.

Although the reform in Tunisia dates back to
1987, the WUAs law was not enacted until 1990 and then was liberalised in 1992. Over 960 WUA were legalised by 2000 and they controlled 56 per cent of the irrigated area under public schemes. The average size of a WUA is about 122 ha with 100 members. Only 30 per cent of WUAs were able to cover their O\&M costs without any public subsidy. Maintenance of the system is still done by the Regional Authorities for Agricultural Development (CRDAs). In a review of the water sector, the Director General of Water Resources (1998) reports that WUAs were very dependent on the CRDAs and did not show any real ability to manage water, as illustrated by the poorly maintained delivery systems. The constraints to WUA effectiveness include: (1) the lack of co-ordination between the Ministries of Agriculture, Interior and Finance, (2) the absence of enterprises in the rural areas which specialise in maintenance of hydraulic systems, (3) the need for renovation of the conveyance systems managed by CRDAs and (4) strong admini-strative control over the WUAs, including the nomination of members by the government which limits local decision-making. In addition, the WUAs must present their budget to the Governor and then wait for his approval. Finally, there is ex post financial control by the local Director of the Ministry of Finance. This all exhibits an exaggerated fear of the misuse of public funds and has caused unnecessary financial rigidity, which has increased management costs and reduced flexibility.

These four cases illustrate that, under certain institutional settings, WUAs appear to be difficult to establish or maintain and in such cases they are not likely to constitute a sustainable solution to water management problems. For such management and institutional reforms to work, the following conditions need to be in place:

1 The country needs a functioning legal system or some other effective alternative means for resolving water conflicts.

2 Decisions concerning reform and future water management, particularly financial decisions, need to be made in an effective and transparent manner. 
3 Users need to have assurances that the government will do what they say they will do, particularly regarding the reforms and transfers of funds.

In meeting these conditions, countries with private sector participation in the provisions of urban water and wastewater management services may be able to transfer this experience to the irrigation sector. Even private management experience from other sectors, such as electricity, gas, and telecommunications, can be helpful in making changes in the irrigation sector since many of the institutional requirements are the same.

In some cases alternative models need to be tried, such as management contracts. Egypt, for example, has used contracts for the operation and maintenance of pumping stations. Mali has gone a step further and established the Office $d u$ Niger as a private enterprise with shares held by the Government, which is in charge of managing the irrigation network under a threeyear performance contract. Elected farmers participate on governance committees with Office du Niger's staff (Deimer, 2002: 21-2). Mexico considered private management of their main irrigation canals, but instead gave the responsibility to limited-responsibility companies (Palacios, 1999: 10-14). The Mexico case has the advantage that farmers are participating in the capital and management decisions.

Whatever model is used, more attention is needed to develop improved ways to define water rights or water-use rights particularly for small farms and to establish clear agency and user responsibilities. This will be important in clarifying for farmers what they will receive in terms of water deliveries. Once farmers have well-established water rights, the dynamics of water management change. It now becomes the responsibility of the water management unit to deliver water effectively to farmers or WUAs.

\subsection{Incentives and cost recovery}

Low water prices and the lack of economic incentives for efficient water use have been a concern for many years. Yet there is a large number of stakeholders who do not think higher water prices are appropriate. One view is that on-farm and household efficiency in water use are not important and that basin efficiency is the key since water lost by run-off or percolation will be used downstream. Another argument is that small-scale farmers and low income households do not have enough income to pay the full costs of water, or that for farmers the value of water has been capitalised into land values. Another concern is that farmers may have to pay for the government's mistakes in building unprofitable, badly-designed, poorlymanaged and overstaffed projects to increase food production and lower food prices. In addition, it is difficult to measure the volume of water each farm receives in big irrigation systems that serve large numbers of small-scale farms. Consequently, water prices and cost recovery (30-50 per cent of O\&M costs) have been relatively low in many developing countries (Dinar and Subramanian, 1997: 155$6)$.

Thus ministries of finance and international organisations, such as the World Bank, have found it difficult to get countries to raise their price of water and increase the incentives for improved water use. Nevertheless, there is growing support for the proposition that farmers served by projects designed to increase irrigated agricultural production and farm income should pay the O\&M cost of irrigation and at least contribute something toward capital cost. To reach this goal, several new and innovative approaches have been tried, including water markets, capacity sharing and private financing of water infrastructure.

Water markets with their incentives for efficient water use is not a new idea, but it has gained support in recent years. One example of successful water markets comes from Chile where they were built on effective WUAs, wellmanaged infrastructure, and registration private water rights based on past use. These private rights are separated from land and have the same legal standing as other property rights. There are few conditions set on prices or water use by buyers (Thobani, 1998: 38). Chile's history of direct involvement of the private sector in irrigation development provided a good basis 
for introducing water rights and water markets in 1981 (Hearne, 1998: 142-4).

In the developed countries, such as the United States, water markets have emerged as a response to environmental concerns regarding new projects, escalating costs of new supplies, and the growing demands for additional water. Markets are an economic mechanism for increasing efficiency and adding flexibility through allowing voluntary transfers of water. In South Africa the trading of water rights has occurred in certain schemes, such as the Hereford irrigation scheme. Another option being considered in South Africa is reservoir capacity sharing (Gakpo, Du Plessis \& Viljoen, 2001: 90-1). In capacity sharing water users buy long-term or perpetual rights to storage capacity in a reservoir. Those rights can be bought and sold on a permanent or temporary basis. Gakpo et al. (2001: 91) point out that "the concept of capacity sharing is known to be operational only in two countries, namely Zimbabwe and Australia". The first capacity sharing scheme in the Mazowe Catchment in Zimbabwe dates back to 1984, when eleven commercial farmers formed the first 'Combined Irrigation Scheme' (CIS) as described in the Zimbabwe Water Act of 1976. The entire CIS was legally considered as having a single water right. Therefore, there was no legal reason why members of the CIS should not manage their individual sub-rights as described as long as there was no prejudice to other right holders.

In contrast to South Africa, water trading in Morocco and Tunisia has been limited to a few informal trades. One reason water markets have not been implemented in Tunisia is the limited pipe capacity in some systems during periods of high irrigation water demands and the high transaction costs of transferring water to urban users. The opportunity cost of water in farming is high during periods of peak water demand, particularly in areas producing high valued crops, again reducing net returns from trading water to other areas or sectors. In contrast, Diao and Roe (2003: 708) found that water trading in Morocco, combined with market liberalisation in agriculture, would raise water allocation efficiency and benefit the whole economy.
Water trading is not just between actual users. For example, WUAs in Mexico negotiate contracts for water at the end of winter season with prices either freely agreed upon between traders and/or fixed by the CNA (Comisión Nacional del Agua). The prices are not likely to reflect the scarcity value of water since cooperation between the WUAs, who are members of a Limited Responsibility Company, plays a major role in the water exchanges (Kloezen, 1998: 452). However, since water rights are held by WUAs and not by the farmers, trading may be limited by the lack of incentives for farmers to sell water and use it efficiently.

In cases where variability in supply or demand is a key concern, the option or contingent transfer contract is a good market approach to consider. With a contingent market the seller agrees to deliver water to the buyer, at a price, whenever predefined conditions are met. A buyer purchases a call option paying a value $C$ for the call option. At the end of the expiration date the holder of the call option must decide whether to purchase the water or not, while the seller is required to provide the water if the call is exercised. When the owner of the call option decides to buy the water, he or she has to pay the strike price $K$ for the water as specified in the call option. If the option is not used, the seller of the call option keeps the value of the option and remains the owner of the water. Option contracts for water are likely to be more complicated than the above example in the sense that the period of time, or expiration date, could be longer than one year and the possibilities to call can be multiple times during the period (Villinski, 2002: 12-13). One example of such an option was the option bank that the California Department of Water Resources (CDWR) initiated at the end of 1994. However, no calls were made owing to improved rainfall; consequently sellers kept their option payment and were free to use or resell the water. This was a publicly managed market, and the prices were fixed by the CDWR (Howitt, 1998: 131).

\subsection{Environmental improvements and externalities (a basin approach)}

Sub-Saharan Africa needs to follow an integrated water management strategy, but may 
find it difficult to do so. "Every Sub-Saharan African country shares one or more rivers with its neighbors and many countries see most of their waters flowing from or to other countries" (Grey, Gilgan-Hunt, Sharma, Roth, Damhaug \& Okau, 1996: 34). "There are at least fiftyfour rivers or water bodies that cross or form international boundaries in the region. Few of the transboundary river basins in the region are effectively jointly managed, and there are many downstream countries that depend on water flow via upstream rivers" (Grey et al., 1996: 35-6). In this context, the Lesotho Highlands integrated water management scheme seems to be an exception. It involves a large, regional, binational, water rights trade between Lesotho and South Africa. If completed, the Scheme "will double the water resource available to the Gauteng region, which is the economic and industrial heartland of southern Africa, sustaining its continued development, while at the same time greatly benefiting Lesotho" (de Villiers, Schmitz \& Booysen, 1996: 73). Still some environmental concerns have still been raised involving possible ecological impacts of such a large transfer of water.

Another positive development in river basin co-ordination in Africa is the Nile Basin Initiative. It is led by the Council of Ministers of Water Affairs of the Nile Basin States and supported by a small secretariat based in Entebbe, Uganda. The action program includes basin-wide technical assistance projects designed to lay the foundation for co-operative action and two sub-basin investment programs (World Bank, 2003: 80-1).

Given the environmental concerns that are raised about large water projects such as the Lesotho scheme and the level of African development, future water development will likely be focused on smaller scale projects. This is the best approach for much of SSA given its experience with large-scale irrigation. Large irrigation projects are complex and are difficult to organise effectively for large numbers of small farms of less than a hectare. In addition, new irrigation should proceed slowly since in many countries there is a general lack of information about water resources and especially about groundwater resources (Lazarus, 1997: 48).

\subsection{Co-ordination between agriculture and irrigation?}

In many countries there has been a continued failure of irrigation and agricultural agencies to coordinate their activities to help increase agricultural production in irrigated areas. In fact, as noted above, lack of co-ordination among ministries in Tunisia is one of the three reasons given for the failure of WUA. Most new or expanded irrigation projects need technical irrigation and agricultural production assistance, as well as marketing services provided by extension agents and an expanded private sector. Without adequate supplies of inputs and reasonable market outlets for the agricultural products, irrigated output will be limited by downward pressure on product prices and limited input supplies especially in SSA were agricultural productivity is already low.

An example of the adverse consequences of inadequate input and product markets is the failure of smallholder schemes in South Africa where parastatals have withdrawn. "Most smallholder schemes in South Africa are located in former homelands in remote areas away from towns and cities with which they often have poor market linkages" (Shah et al., 2002: 7). With the withdrawal of parastatals, there is now a huge institutional vacuum. Both input and output markets that were available under parastatal schemes have disappeared, on these smallholder schemes in the Northern Province of South Africa (Shah et al., 2002: 7).

What is needed is a well co-ordinated package of irrigation and agricultural extension assistance delivered jointly. The agricultural extension would be focused on crop production practices. Irrigation extension, which is almost non-existent in SSA, would provide information concerning how to determine moisture stress, how much water to apply, methods for controlling salinisation, how to avoid water logging and soil erosion, and how and when to do maintenance. Where irrigation extension exists, it is a top-down approach. Irrigation extension views farmers as labour and their role is to implement operations according to specific instructions. This is in contrast to considering extension as a two-way communication between 
technicians and farmers where both learn from the exchange.

The failure of extension efforts is closely related to the lack of an active private sector, which has been seriously retarded by government policies in many developing countries (Easter, 2000: 382-3). Clearly, African countries must promote private and cooperative enterprises in areas where parastatals have abandoned smallholder irrigation projects. Hopefully these enterprises can help fill some of the gaps left by parastatals. Part of the problem is that the presence of the parastatals has depressed private sector development and they cannot be expected to appear without official encouragement.

\subsection{Investment decisions (infrastructure)}

Investment in irrigation poses a real dilemma for SSA countries. The number of farms under one hectare in size is large and growing. This growth is projected to continue, as Africa is the only region of the world forecast to have a growth in rural population through 2030. In addition, these small farms have low productivity and many of those with irrigation have had high O\&M costs relative to farm income and to costs in other countries (Table 1). In fact, many small-scale farmers who are served by pumped irrigation systems cannot take advantage of the management control offered by such systems because of the high $\mathrm{O} \& \mathrm{M}$ costs. Finally, poverty in Africa is very high among the growing population of smallscale farmers.

\section{Table 1}

Cost of South African irrigation as a percentage of gross farm income

\begin{tabular}{|l|c|c|}
\hline \multirow{2}{*}{ Description } & \multicolumn{2}{|c|}{ Type of project } \\
\cline { 2 - 3 } & $\begin{array}{c}\text { Irrigation } \\
\text { board } \\
\text { system (\%) }\end{array}$ & $\begin{array}{c}\text { Smallholder } \\
\text { system } \\
\mathbf{( \% )}\end{array}$ \\
\hline $\begin{array}{l}\text { Full cost as percentage } \\
\text { of gross farm income }\end{array}$ & 1 & $12-16$ \\
\hline $\begin{array}{l}\text { Full cost as percentage } \\
\text { of net farm income }\end{array}$ & $1-1.5$ & $30-35$ \\
\hline
\end{tabular}

Source: Shah et al., 2002.
Developing an irrigation investment strategy that can be effective for small-scale farmers is a real challenge. Yet it can help many African countries to move closer to meeting their goals of an equitable distribution of water resources and increased economic development. What the investment strategy would look like is not clear. But it is clear that decisions concerning design and management need explicitly to take into account the small-holder clientele and help them increase their productivity since yields in SSA are low compared to other areas.

One part of this strategy will be increased infrastructure investment. With its high rainfall variability and low storage capacity in reservoirs, new investments in water resource infrastructure will be important. However, Africa faces high costs in infrastructure development relative to other regions (SSA $\$ 8300$, North Africa $\$ 6,800$, and South Asia \$2 500) (Rosegrant \& Perez, 1997: 29). This is also true for rehabilitation costs, which are at least four times the costs in India and China (SSA \$2 100, India \$260-\$550, China \$140\$440) (Rosegrant \& Perez, 1997: 40; Easter, 2000: 383). Yet "at their present stages of economic and water resources development", Rosegrant and Perez (1997: 13) argue that "most of Sub-Saharan Africa will likely be primarily concerned with supply augmentation" as opposed to demand management

One effective approach is to have the government play a more limited role and only provide indirect investment that leaves ownership and management of the system with the users (Coward, 1986: 239-41). The indirect investment involves grants, loans, technical expertise and legal assistance to implement privately owned and managed irrigation development. Brown and Nooter (1992: x-xi) argue this will work best when "(a) technology is simple and low cost, ... (b) the institutional arrangements for operating the system are private ..., (c) the supporting infrastructure is adequate to permit access to inputs and to markets for the sale of surplus production, (d) the systems generate high and timely cash returns to farmers, and (e) the farmer is an active and committed participant in project design and implementation". 
Rosegrant and Perez (1997: 34) find "that areas under farmer controlled small-scale systems have grown rapidly over the past decades and account for a large and growing share of irrigated area in Sub-Saharan Africa". Both Niger and Nigeria have had significant private irrigation development. In Niger private development of shallow groundwater has irrigated 60000 ha, while in Nigeria about 800000 ha have been irrigated by farmer initiated and controlled small-scale irrigation.

Burt and Styles (1998) in their review of projects designed to improve government irrigation in 16, primarily large, developing country schemes found that hardware improvements were almost always needed. Without key design and hardware changes, the promotion of WUAs would likely fail. Although most design changes were relatively simple, they needed to be integrated with operational and management changes. They argue that one of the key elements is how water moves and is controlled throughout an irrigation project in terms of both hardware and operations. Design changes can significantly reduce the transaction costs of managing and delivering water, but these changes will require increased expenditure on infrastructure. Finally, for systems serving large numbers of small farms to be effective, additional design changes and costs are likely to be required.

An important question involves the sequence of government investments and institutional development in water projects. If rehabilitation occurs before the system is turned over to users, then users must be involved in planning the rehabilitation, especially if they are expected to repay costs and provide O\&M. In small-holder systems in Africa, the first step may need to be to help farmers increase productivity and incomes before major rehabilitation can be considered. User involvement will be critical in designing effective irrigation investments that reduce the costs of water management and increase agricultural productivity.

A particular concern for government is whether or not to rehabilitate projects where the estimated benefits are less than rehabilitation costs. Based on strictly economic analysis, the projects would be rejected. This poses a real dilemma for many African countries that do not need more migrants moving to their already overcrowded cities. Irrigated agriculture can provide employment for many families and keep them from moving to urban areas. Such projects may also create employment and other benefits, such as village water supply and fishing that are normally not counted as benefits in irrigation projects.

A third issue involves a country's interest and abilities to value environmental impacts of water projects. A complete economic analysis is required for most large-scale irrigation, but good examples of such analysis in developing countries are still limited (Tubpen, 1986: 13545, and Easter, Dixon \& Hufschmidt, 1991: 5369). International funding of the environmental component of such studies would help improve the studies. For projects funded with internal funds, there are few incentives for a country to include information on negative environmental impacts in their project evaluations. China's Three Gorges dam is a prime example of environmental concerns being discounted. The same problem has occurred in large water projects in Africa and South Asia. Yet pressure from environmental groups is now limiting funding of large water projects by international agencies and will be a major consideration in future development of water in Africa.

A fourth issue involves measuring not only the full cost but the full benefits of irrigation projects. In a number of cases benefits for other water uses in irrigation projects are important but not counted. For example, domestic water supply, fish production, livestock water, industrial water use, and small-scale hydropower can be important benefits that are not included. In three large projects in India these uncounted benefits ranged from 6 to 12 per cent of total ex-post benefits. In addition, there may be secondary benefits because of expanding input demands and the need to market the increased output. In project evaluation we will need to do a better job of counting the full cost and benefits of irrigation projects.

Even with the measurement of all benefits and an expanded investment in irrigation infrastructure in SSA, the added irrigation is 
not likely to solve the projected shortfall in food production. Sub-Saharan Africa does not have the large areas suitable for irrigation that Asia has had in the last half century. Rosegrant and Perez (1997: 24) found that "The amount of land under irrigation and the potential exploitable relative to total crop area is simply not large enough to generate revolutionary changes in crop production. However, the impacts that are generated from investment in irrigation are important. Probably the most significant impact is the reduction in cereal imports in Sub-Sahara from 29 million metric tons to 14 million metric tons in $2020 "$ "

\section{4 \\ Conclusion}

Two aspects are clear about irrigation reform and investment in Africa. First, there are no silver bullets or simple solutions that will fit all or even most situations. Second, the stage and need for reform in SSA is different from that in Asia. The articulated need for reform in SSA is not as strong as it is in Asia, primarily because the level of irrigation development in Africa is lower.

Another key difference is the productivity of the small-scale farms, which is significantly lower in SSA than in Asia. The growth in rural population in Africa means the number of small farms will increase in the future. Also, many of the small-holder schemes in SSA are pumping systems with high $O \& M$ costs. A further difference is that many of the small-holders are women and their cropping income is only a small part of total income. In addition, these small-holders are likely to have insecure land tenure, which takes away any incentive to improve larger run productivity.

In a number of respects African and Asian countries have experienced similar water problems. Countries in both regions have had difficulty in organising effective WUAs that serve small-holders. As a result a few countries in both regions have started experimenting with alternative models for delivering water services, such as management contracts.
On the economic side, both regions have had difficulty collecting irrigation fees just to cover O\&M costs. This failure has lead some countries in the two regions to try water markets as an alternative means to improve water use efficiency and water allocation. An important part of establishing water markets is assigning water rights. If done effectively, this can create very positive incentives for improving water use.

Environmental concerns involving large water projects are quite similar in the two regions. Where Africa is different, is in the large number of international rivers that need to be managed effectively. Thus, although countries in both regions see the need for integrated water management, to implement a successful integrated strategy in Africa is going to be a more difficult task.

Not surprisingly, both regions have a problem with conflicting ministries serving irrigation and agriculture. The long-run solution to this problem is to encourage the private sector to supply agricultural inputs and provide markets and transportation for the production from the irrigated farms. It also may mean expanded private sector management of failed public water systems.

Finally, the investment strategy may need to be different for the two regions. Small-scale farms are the norm for much of SSA and Asia. But the productivity of small holders in Africa has lagged behind their Asian counterparts. Thus the investment strategy for SSA irrigation has to give increasing productivity a high priority. For both regions future investments in irrigation need to focus on the needs of smallscale farms. In many cases, this will change the investment emphasis to small-scale projects with active user participation and to indirect investment supporting private small-scale irrigation development. For direct government investment in projects, infrastructure investments must be made jointly with decisions about the project's management structure. The old approach of building the infrastructure first and then worrying about management just does not work. 


\section{Endnote}

1 The authors would like to thank Yoshifumi Konishi for his help in gathering and reviewing information and documents dealing with water resources issues in South Africa and other African countries.

\section{References}

1 BRISCOE, J. (1997) "Managing water as an economic good: Rules for reformers," Water Supply, 15(4): 153-72, Harrogate: Yorkshire.

2 BROWN, E.P. \& NOOTER, R. (1992) "Successful small-scale irrigation in the Sahel", World Bank Technical Paper No. 171, World Bank: Washington D.C.

3 BURT, C.M. \& STYLES, S.W. (1998) "Modern water control and management practices in irrigation: Impact and performance", Report to the World Bank Research Committee:

Washington, D.C.

4 COWARD, E.W. (1986) "Direct or indirect alternatives for irrigation investment and the creation of property," in Easter, K. William (ed.) Irrigation Investment, Technology and Management Strategies for Development, Westview Press: Boulder, CO.

5 DAHLMAN, C.J. (1979) "The problem of externality," Journal of Law and Economics, 22: 141-61.

6 DEIMER, G. (2002) "Bank-financed irrigation and drainage projects: review of institutional components," World Bank Technical Paper \# 524, in Institutional Reform for Irrigation and Drainage.

7 DE VILLIERS, G.D.T; SCHMITZ, P.M.U. \& BOOYSEN, H.J. (1996) "South Africa's water resources and the Lesotho Highlands Water Scheme: A partial solution to the country's water problems," International Journal of Water Resources Development, 12(1).

8 DIAO, X. \& ROE, T. (2003) "Can a water market avert the 'double-whammy' of trade reform and lead to a 'win-win' outcome?", Journal of Environmental Economics and Management, 45(30): 708-23.

9 DINAR, A. \& SUBRAMANIAN, A. (1997) "Water pricing experiences on international perspective," World Bank Technical Paper \#386.

10 DIRECTION GÉNÉRALE DES RESOURCES EN EAU (1998) "Etude du Secteur de l'Eau en
Tunisie”, Bechtel Inc \& SCET-Tunisie, Ministry of Agriculture, Direction Générale des Resources en Eau: Tunisia.

11 EASTER, K.W.; DIXON, J.A. \& HUFSCHMIDT, M.M. (1991) Watershed Resource Management (Studies from Asia and the Pacific), Institute of Southeast Asian Studies: Singapore.

12 EASTER, K.W. (2000) "Asia's irrigation management in transition: A paradigm shift faces high transaction costs", Review of Agricultural Economics, 22(2): 370-88.

13 EL HASNAOUI, A.; BOULASSEL, A. \& RAKI, M. (2002) "Freins socio-economiques a la valorisation de l'eau dans les grands perimetres irrigues au Maroc", Paper presented at the Agadir Conference on Irrigation Water Policies: Micro and Macro Considerations: Agadir, Maroc, June.

14 GAKPO, E.F.Y., DU PLESSIS, L.A. \& VILJOEN, M.F. (2001) "Towards institutional arrangements to ensure optimal allocation and security of South Africa's water resources", Agrekon, 40(1) March: 87-103.

15 GREY, D.; GILGAN-HUNT, E.; SHARMA, N.; ROTH, D. \& OKAU, V. (1996) "African water resources: Challenges and opportunities for sustainable development", World Bank Technical Paper No. 331, September.

16 HEARNE, R.R. (1998) "Institutional and organisational arrangements for water markets in Chile”, in Easter, K.W., Dinar, A. \& Rosegrant, M.W. (eds.) Markets for Water: Potential and Performance, Kluwer Academic Publishers: Boston.

17 HOWITT, R. (1998) "Spot prices, option prices, and water markets: An analysis of emerging markets in California", in Easter, K.W., Dinar, A. and Rosegrant, M.W. (eds.) Markets for Water: Potential and Performance, Kluwer Academic Publishers: Boston.

18 KLOEZEN, W.H. (1998) "Water markets between Mexican user associations", Water Policy, 1: 437-55.

19 LAZARUS, P. (1997) “Towards a regulatory framework for the management of groundwater in South Africa", Report to the Water Research Commission and the Department of Water Affairs and Forestries, WRC report \#789/1/98, DWAF report \#Geo 202 (389).

20 MORIS, J. \& THOM, D.J. (1990) Irrigation Development in Africa: Lessons of Experience, Westview Press: Boulder, CO.

21 PALACIOS, E.V. (1999) "Benefits and second generation problems of irrigation management 
transfer in Mexico", Economic Development Institute Participatory Irrigation Management Case Studies Series, sponsored by the Economic Development Institute of the World Bank and the International Irrigation Management Institute, June.

22 PERRET, S.R. (2002) "Water policies and smallholding irrigation schemes in South Africa: A history and new institutional challenges", Water Policy, 4(3): 283-300.

23 ROSEGRANT, M.W. \& PEREZ, N.D. (1997) "Water resources development in Africa: A review and synthesis of issues, potentials, and strategies for the future", EPTD Discussion Paper \#28, IFPRI, Sept.

24 SHAH, T.B.; KOPPEN, V.; MERRY, D.; LANGE, M. \& SAMAD, M. (2002)

"Institutional alternatives in African smallholder irrigation: Lessons from international experience with irrigation management transfer", IWMI Research Report \#60, Sri Lanka.

25 SIMAS, J. (2002) "Issues affecting irrigation and drainage sectors in Latin America: Lessons from Mexico, Argentina and Brazil", World Bank Technical Paper \#524 in Institutional Reform for Irrigation and Drainage, Washington, D.C.

26 THOBANI, M. (1998) "Meeting water needs in developing countries: resolving issues in establishing tradable water rights", Easter, K.W.,
Dinar, A. \& Rosegrant, M.W. (eds.) Markets for Water: Potential and Performance, Kluwer Academic Publishers: Boston.

27 TUBPAN, Y. (1986) "The economics of small tank irrigation”, in Easter, K. William (ed.)

Irrigation Investment, Technology, and Management Strategies for Development, Westview Press: Boulder, CO: 129-46.

28 VILLINSKI, M.T. (2002) "A financial economics approach to pricing multiple-exercise option contracts for water", Draft Ph.D. Dissertation, Department of Applied Economics, University of Minnesota, St. Paul, MN, July.

29 WILliAMSON, O.E. (1985) The Economic Institutions of Capitalism, Free Press: New York, NY.

30 WORLD BANK (1993) Water Resources Management (A World Bank Policy Paper). World Bank: Washington, D.C.

31 WORLD BANK (2003) "Water resources sector strategy: Strategic directions for World Bank engagement", Draft World Bank paper, Feb.

32 ZEKRI, S. \& EASTER, K.W. (2003) "Institutional and organisational reforms in LDCs: Management transfers, private managers and water markets", Draft paper, Dept. of Applied Economics, University of Minnesota: St. Paul, Minnesota. 